Article

\title{
Ecological Risk Assessment and Contamination History of Heavy Metals in the Sediments of Chagan Lake, Northeast China
}

\author{
Panfeng Liu ${ }^{1,2}$, Chaojie Zheng ${ }^{1}$, Meilan Wen ${ }^{1, *}{ }^{+}$, Xianrong Luo ${ }^{1}$, Zhiqiang Wu ${ }^{2, *}$, Yinghong Liu ${ }^{1}$, Sheli Chai ${ }^{3}$ \\ and Liangliang Huang ${ }^{2}$ (D) \\ 1 College of Earth and Sciences, Guilin University of Technology, Guilin 541006, China; \\ panfengliu@glut.edu.cn (P.L.); zcj@glut.edu.cn (C.Z.); 1xr811@glut.edu.cn (X.L.); 6611053@glut.edu.cn (Y.L.) \\ 2 College of Environmental Science and Engineering, Guilin University of Technology, Guilin 541006, China; \\ llhuang@glut.edu.cn \\ 3 College of Geo-Exploration Science and Technology, Jilin University, Changchun 130012, China; \\ chaisl@jlu.edu.cn yahoo.com.cn \\ * Correspondence: 2004006@glut.edu.cn (M.W.); wuzhiqiang@glut.edu.cn (Z.W.); \\ Tel.: +86-139-7837-2296 (M.W.); +86-187-7718-0208 (Z.W.)
}

Citation: Liu, P.; Zheng, C.; Wen, M.; Luo, X.; Wu, Z.; Liu, Y.; Chai, S.; Huang, L. Ecological Risk

Assessment and Contamination History of Heavy Metals in the Sediments of Chagan Lake, Northeast China. Water 2021, 13, 894. https:// doi.org/10.3390/w13070894

Academic Editor: Maria Gavrilescu

Received: 2 February 2021

Accepted: 18 March 2021

Published: 25 March 2021

Publisher's Note: MDPI stays neutral with regard to jurisdictional claims in published maps and institutional affiliations.

Copyright: (c) 2021 by the authors. Licensee MDPI, Basel, Switzerland. This article is an open access article distributed under the terms and conditions of the Creative Commons Attribution (CC BY) license (https:// creativecommons.org/licenses/by/ $4.0 /)$.
Abstract: The study deals with the spatio-temporal distribution of heavy metals in the sediments of Chagan lake, Northeast China. The pollution history of heavy metals is studied simultaneously through the ${ }^{210} \mathrm{~Pb}$ dating method by analyzing the characteristic of $\mathrm{As}, \mathrm{Hg}, \mathrm{Cd}, \mathrm{Cr}, \mathrm{Ni}, \mathrm{Cu}, \mathrm{Pb}$, and $\mathrm{Zn}$ concentration-depth profiles. The potential ecological risk index $(R I)$ and geo-accumulation index ( $\left.I_{g e o}\right)$ were used to evaluate the contamination degree. Principal component analysis (PCA), based on the logarithmic transformation and isometric log-ratio (ilr) transformed data, was applied with the aim of identifying the sources of heavy metals. The element concentrations show that the heavy metals are enriched in the surface sediment and sediment core with a varying degree, which is higher in the surficial residue. The results of $I_{g e o}$ indicate that the $\mathrm{Cd}$ and $\mathrm{Hg}$ in the surface sediment have reached a slightly contaminated level while other elements, uncontaminated. The results of $R I$ show that the study area can be classified as an area with moderate ecological risk in which $\mathrm{Cd}$ and $\mathrm{Hg}$ mostly contribute to the overall risk. For the sediment core, the ${ }^{210} \mathrm{~Pb}$ dating results accurately reflect the sedimentary history over 153 years. From two evaluation indices ( $R I$ and $I_{\text {geo }}$ ) calculated by element concentration, there is no contamination, and the potential ecological risk is low during this period. The comparative study between raw and ilr transformed data shows that the closure effect of the raw data can be eliminated by ilr transformation. After that, the components obtained by robust principal component analysis (RPCA) are more representative than those obtained by PCA, both based on ilr transformed dataset, after eliminating the influence of outliers. Based on ilr transformed data with RPCA, three primary sources could be inferred: $\mathrm{Cr}, \mathrm{Ni}, \mathrm{As}, \mathrm{Zn}$, and $\mathrm{Cu}$ are mainly derived from natural sources; the main source of $\mathrm{Cd}$ and $\mathrm{Hg}$ are associated with agricultural activities and energy development; as for $\mathrm{Pb}$, it originated from traffic and coal-burning activities, which is consistent with the fact that the development of tourism, fishery, and agriculture industries has led to the continuous increasing levels of anthropogenic $\mathrm{Pb}$ in Chagan Lake. The summarized results and conclusions will undoubtedly enhance the governmental awareness of heavy metal pollution and facilitate appropriate pollution control measures in Chagan Lake.

Keywords: heavy metal in sediment; ${ }^{210} \mathrm{~Pb}$ dating; isometric log-ratio (ilr) transformation; source analysis; Chagan Lake

\section{Introduction}

Lake sediments are the terminal point of material accumulation in the River Basin and the reservoir of potential pollution sources (such as heavy metals, organic matter, etc.) entering the lake [1-4]. The chemical constituents in lake sediments can reflect the weathering 
and denudation process of rocks in the area, which can act as a good indication for environmental pollution and natural environment changes around the lake [5-7]. In addition, there is a certain material exchange between the sediment and lake water. The changes in the lake environmental conditions will potentially lead to the transfer of heavy metals from sediments to lake water, which will become the secondary water pollution sources, potentially affecting water quality and aquatic organisms in the lake [8-11]. Therefore, it is of particular interest to study the spatial variation of element content in lake sediments, which can be crucial in tracing the source of pollution substances, and to reveal both the environmental variation and the possible influence of human activities on the water quality of the lake.

Chagan Lake is an important ecological barrier, a vital fishery base, and a famous tourist area in the west of Jilin Province. It plays an essential role in regulating climate, protecting regional biodiversity, developing ecological industry, and maintaining regional ecological balance $[12,13]$. In the past, the water source of Chagan Lake was mainly derived from the Huolin River. However, after the middle and lower reaches of the Huolin River were cut off due to the construction of the Hangali, Xinglong, and Shengli water storage projects, which caused the lake area to shrink, problems have followed one after another. The current water sources carry significant salt and alkali into Chagan Lake after passing through salinized grassland, leading to the salinization of the lake. Additionally, the tourism of Chagan Lake has also achieved unprecedented development, and the Changshan chemical fertilizer plant and thermal power plant have been built nearby. Further, there is some irrigation water from rice production around the lake which has entered Chagan Lake [14]. These may have a certain impact on the water quality of the lake. In addition, under the influence of global climate change and human activities, Chagan Lake has been facing severe ecological and environmental problems (such as agricultural diffuse pollution source, salinization, heavy metal pollution, etc.). Although some studies have assessed the levels of heavy metal pollution in Chagan Lake [14-17], temporal variations and source identification of heavy metals in sediments remain poorly documented. In this study, surface and core sediment samples collected from Chagan Lake were analyzed for the following specific objectives: (1) to investigate the spatial distribution of heavy metals in surface sediments; (2) to establish a historical record of heavy metal pollution by analyzing the profiles of sediment cores; and (3) to evaluate the pollution intensity of heavy metal using the potential ecological risk index $(R I)$ and geo-accumulation index $\left(I_{g e o}\right)$. Based on the logarithmic transformation and isometric log-ratio (ilr) transformation of raw data, principal component analysis (PCA) was applied to distinguish the possible sources of heavy metals, which can provide a scientific basis for the environmental protection of soil ecosystem and comprehensive treatment of heavy metal pollution in this region.

\section{Materials and Methods}

\subsection{Study Area}

Chagan Lake is the largest natural lake in Jilin Province and the tenth-largest lake in China. It is located in the Mongolian Autonomous County of Qian Gorlos in the western region of Jilin Province in Northeast China (E $124^{\circ} 03^{\prime}-124^{\circ} 34^{\prime}, \mathrm{N} 45^{\circ} 09^{\prime}-45^{\circ} 30^{\prime}$; Figure 1a) [18-20]. The surface area of the lake is $372 \mathrm{~km}^{2}$, with an average depth of $1.52 \mathrm{~m}$. The region's climate belongs to the Continental semi-arid monsoon climate, with an annual average temperature of $4-5{ }^{\circ} \mathrm{C}$. The average yearly precipitation and evaporation level is around $400-500 \mathrm{~mm}$ and $1140-1270 \mathrm{~mm}$, respectively. The water storage in the lake, depending on the climate conditions, varies significantly with the seasons. The water source of Chagan Lake derives from the Songhua River, Huolin River, Tao'er River, and Nenjiang River, as shown in Figure 1b. In addition, natural precipitation and groundwater also play a role as ancillary water suppliers for the lake. The region is also a tourist area famous for its salubrious climate and the fishing and hunting festivals in winter. 


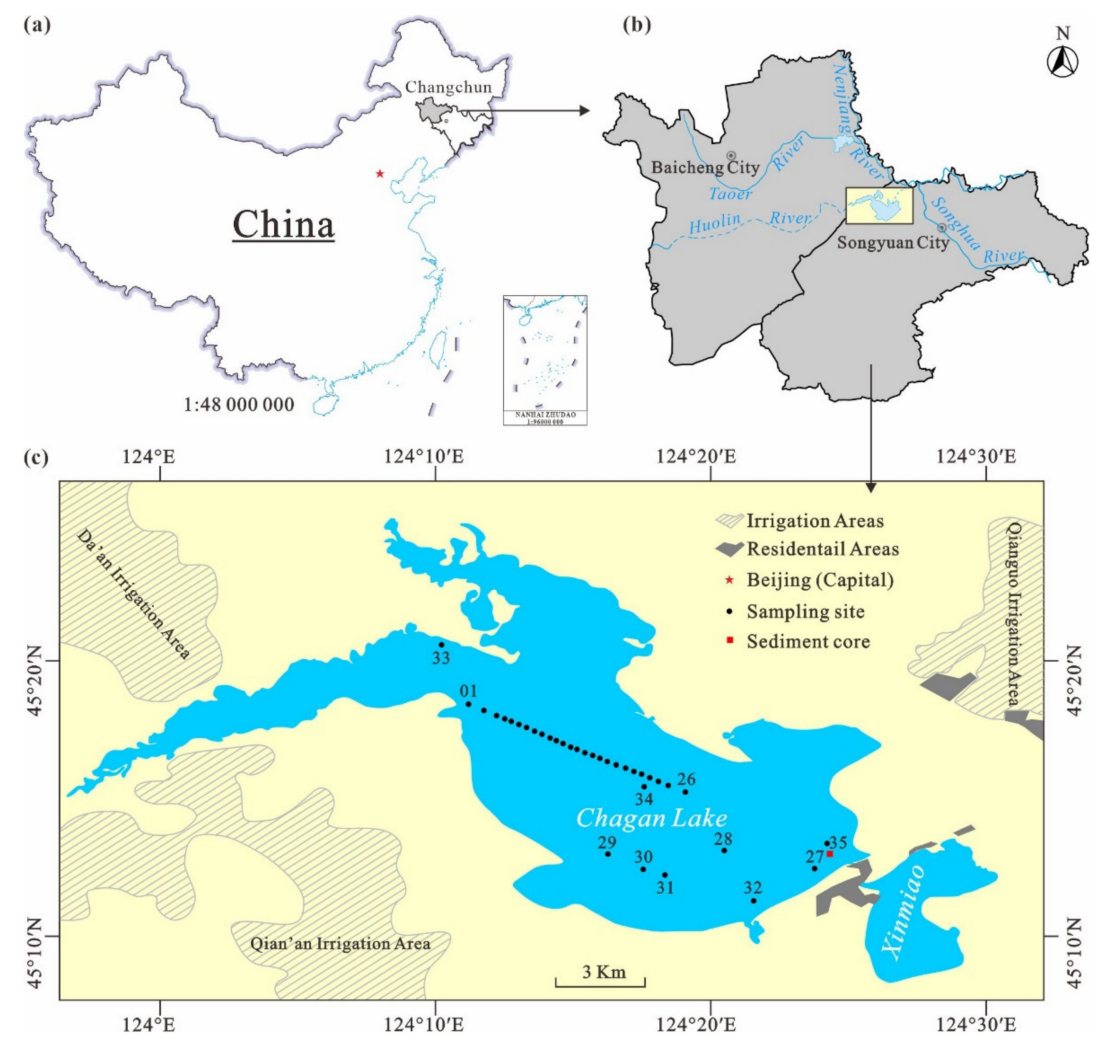

Figure 1. Geographic setting of Chagan Lake $(\mathbf{a}, \mathbf{b})$ and detailed view of sampling locations (c).

\subsection{Sample Collection and Analysis}

Thirty-five surface sediment samples along with one sediment core (depth of $150 \mathrm{~cm}$ ) were collected from Chagan Lake using a gravity sampler, as illustrated in Figure 1c. Thirty-five surface sediment samples $(0-10 \mathrm{~cm})$ were collected with a pre-cleaned and acid-washed polyvinyl chloride (PVC) spade, and immediately placed in acid-washed polyethylene bags. The sediment core taken, sectioned at $4 \mathrm{~cm}$ intervals, was stored into polyethylene bags under the condition of $4-6{ }^{\circ} \mathrm{C}$. All samples were transported to the laboratory and air-dried for two weeks at ambient temperature. After that, the dried bulk samples were ground with an agate mortar and sieved at the $<100$-mesh fraction for further geochemical and radionuclide analysis [21]. The heavy metals concentrations were analyzed with inductive coupled plasma mass spectrometry (ICP-MS) for $\mathrm{Cd}, \mathrm{Pb}$, $\mathrm{Zn}, \mathrm{Cr}, \mathrm{Cu}$, and $\mathrm{Ni}$ and an atomic fluorescence spectrometer (AFS) for As and $\mathrm{Hg}$. The measurements were carried out in the Jilin Mineral Resources Supervision and Test Center, Ministry of Land Resources, China. The detection limits and relative errors for standards of the corresponding measurement are shown in Table S1.

The radio-isotope activity determination of the sediment samples was conducted at the Institute of Environment and Sustainable Development, Chinese Academy of Agricultural Sciences (CAAS). The ${ }^{210} \mathrm{~Pb}$ activities were analyzed in dry samples $(2-5 \mathrm{~g})$ with highpurity germanium (HPGe) detector (BE5030, LABSOCS, Atlanta, GA, USA) after 25 days of storage in sealed containers for radioactive equilibration. The specific activity of ${ }^{210} \mathrm{~Pb}$ was obtained from $\gamma$-ray counts with $46.5 \mathrm{keV}$ in the energy spectrum, and ${ }^{226} \mathrm{Ra}$ was mainly obtained from the weighted average of $\gamma$-ray counts with $351 \mathrm{keV}\left({ }^{214} \mathrm{~Pb}\right)$ and $609 \mathrm{keV}\left({ }^{214} \mathrm{Bi}\right)$ $\gamma$-ray counts, respectively. The excess ${ }^{210} \mathrm{~Pb}$ activity $\left({ }^{210} \mathrm{~Pb}\right.$ ex $)$ of the sediment samples was determined by subtracting ${ }^{226} \mathrm{Ra}$ activity from the total ${ }^{210} \mathrm{~Pb}\left({ }^{210} \mathrm{~Pb}_{\text {tot }}\right)$ activity [22]. After the measurement, the spectrum was deciphered by a DSA-1000 digital spectrometer, and the spectrum data were analyzed by Genie-2000 spectrum analysis software. All sediment radionuclide concentrations were described in $\mathrm{Bq} / \mathrm{kg}$ dry weight. The test's accuracy and 
precision were referenced by the Chinese national standard GB/T11743-2013 (radionuclide in the soil of gamma energy spectrum analysis method).

\subsection{Contamination and Risk Assessment Methods}

\subsubsection{Potential Ecological Risk Index}

The potential ecological risk index $(R I)$ is widely used to assess the heavy metals contamination of sediments according to the toxicity of heavy metals and the response of the environment [23-26]. The RI can be evaluated through the following formula [27]:

$$
\begin{gathered}
C_{r}^{i}=C_{k}^{i} / C_{n}^{i} \\
E_{r}^{i}=T_{r}^{i} \times C_{r}^{i} \\
R I=\sum E_{r}^{i}=\sum T_{r}^{i} \times C_{r}^{i}=\sum T_{r}^{i} \times\left(C_{k}^{i}\right) /\left(C_{n}^{i}\right)
\end{gathered}
$$

where $C_{k}^{i}$ and $C_{n}^{i}$ represent the measured concentration and background concentration, respectively. $T_{r}^{i}$ is the element toxicity coefficient. In this study, the toxicity coefficients of $\mathrm{As}, \mathrm{Hg}, \mathrm{Cd}, \mathrm{Cr}, \mathrm{Cu}, \mathrm{Pb}$, and $\mathrm{Zn}$ are $10,40,30,2,5,5,5$, and 1, respectively [28]. E $\mathrm{r}_{r}^{i}$ is the potential ecological risk index of the heavy metal (i). $R I$ is the potential ecological risk calculated by the overall contamination. The $E_{r}^{i}$ and $R I$ are divided into five and four classes depending on the criterion given in Table 1.

Table 1. The classification criterion of the potential ecological risk index $E_{r}^{i}$ and potential ecological risk index $(R I)$.

\begin{tabular}{ccc}
\hline$E_{r}^{i}$ & $\boldsymbol{R I}$ & Potential Ecological Risk \\
\hline$E_{r}^{i} \leq 40$ & $R I \leq 150$ & low risk \\
$40<E_{r}^{i} \leq 80$ & $150<R I \leq 300$ & moderate risk \\
$80<E_{r}^{i} \leq 160$ & $300<R I \leq 600$ & relatively high risk \\
$160<E_{r}^{i} \leq 320$ & - & high risk \\
$E_{r}^{i}>320$ & $R I>600$ & extremely high risk \\
\hline
\end{tabular}

\subsubsection{Geo-Accumulation Index}

The geo-accumulation index $\left(I_{g e o}\right)$ is another evaluating indicator often used to assess the pollution in sediments. It takes the influence of human activities and natural geological processes on the background value into account. It can be used to quantitatively evaluate the degree of heavy metal pollution in sediments or other substances [29-32]. The formula for $I_{g e o}$ is defined as [33]:

$$
I_{\text {geo }}=\log _{2}\left(C_{k}^{i} /\left(1.5 \times C_{n}^{i}\right)\right)
$$

where $C_{k}^{i}$ is the concentration of the examined heavy metal in the sediment and $C_{n}^{i}$ is the geochemical background concentration of the heavy metal (i), and factor 1.5 refers to the possible variation in background values caused by lithogenic and weathering effects. The $I_{\text {geo }}$ for heavy metal is classified in seven classes [33] as the following presentation: $I_{g e o} \leq 0$, uncontaminated; $0<I_{\text {geo }} \leq 1$, slightly contaminated; $1<I_{\text {geo }} \leq 2$, moderately contaminated; $2<I_{\text {geo }} \leq 3$, moderately to heavily contaminated; $3<I_{\text {geo }} \leq 4$, heavily contaminated; $4<I_{\text {geo }} \leq 5$, severely contaminated; and $I_{\text {geo }}>5$, extremely contaminated.

\subsection{Data Processing and Analysis}

In geochemistry, compositional data are obtained by transforming the raw dataset whose elements sum is one or $100 \%$ (i.e., $\mathrm{mg} / \mathrm{kg}$ of an element in a sample) into proportions of a whole [34]. In environmental science studies, it is generally accepted that the elements analyzed make up the entirety of the soil on the condition $[35,36]$. Indeed, this issue has been extensively debated and referred to by researchers as the closure problem [37]. It will undoubtedly have implications on the statistical analysis if applied to the raw concentration data. Most standard statistical methods are designed for the Euclidean 
geometry in real space. Therefore, it is preferable to construct a family of "transformations" from the original sample space of compositional data to the real space, where standard multivariate methods can be applied for their statistical processing [38]. The compositional data analysis methodology is based on the information contained in the ratios of the element concentration. Currently, there are three kinds of transformations in processing and analyzing compositional data, namely, alr (additive log-ratio transformation), clr (centered log-ratio transformation), and ilr (isometric log-ratio transformation). Among these transformations, neither alr nor clr transformations can eliminate the closure effect of compositional data, while ilr transform can open the closed dataset. Furthermore, the variables of a raw dataset are reduced after alr and ilr transformation, which definitely increases the difficulty of result interpretation. However, clr transformed data remains the same number of variables as the raw data. After a comprehensive study of Compositional data, Filzmoser tried to process the ilr transformed data based on PCA with an orthogonal basis and then back transform the result of PCA to clr coordinates, which both overcame the closure effect of compositional data and highlighted the geochemical significance of element association. The ilr and clr transformation formulas involved in this paper are as follows [38,39]:

$$
\begin{gathered}
y=\operatorname{clr}(x)=\left(\mathrm{y}_{1}, \ldots, \mathrm{y}_{\mathrm{D}}\right)^{\prime}=\left(\ln \frac{x_{1}}{g(x)}, \ldots, \ln \frac{x_{d}}{g(x)}\right)^{\prime}=\ln \frac{x^{\prime}}{g(x)} \\
Z=\operatorname{ilr}(x)=\left(z_{1}, \ldots, z_{D-1}\right)^{\prime}, \mathrm{Z} j=\sqrt{\frac{D-j}{D-j+1}} \ln \frac{x_{j}}{\sqrt[D-j]{\prod_{k=j+1}^{D} x_{k}}}, j=1, \ldots, D-1
\end{gathered}
$$

where $g(x)$ represents the geometric mean value whose formula is: $g(x)=\sqrt[D]{\prod_{k=1}^{D} x k}=$ $\exp \left(\frac{1}{D} \sum_{k=1}^{D} \ln x k\right)$; in Formula (5), the variable $x$ belonging to D-dimensional simplex space is mapped to $y$ of $D$-dimensional vector space in a one-to-one way; in Formula (6), the variable $x$ belonging to $D$-dimensional simplex space is mapped to $z$ of $D-1$ dimensional hyperplane vector space with $Z j$ as the pivot center.

Principal components analysis (PCA), known as one of the most important multivariate statistical methods, is widely used for dimension reduction and variable association evaluation, which was performed on raw and compositional data in this paper. PCA aims to reduce the dimensionality of data and simultaneously preserve the dataset's inherent variability structure (variance-covariance) [40]. However, the impact of outlier values in the dataset to be analyzed could produce a biased PCA result, which may incur a wrong interpretation of element associations. With the development of robust statistics in the latter 20th century, the improved PCA named Robust principal component analysis (RPCA) was put forward by P.J. Hubcr to tackle this issue [41]. Compared to the conventional PCA method, RPCA constructs a robust covariance matrix to reduce the influence of outliers on covariance, thereby obtaining more reasonable analysis results [42-44]. On this basis, logarithmic and ilr transformed datasets along with raw data were chosen as comparative datasets to perform PCA and RPCA, then PC1 and PC2 components scores of different datasets based on PCA and RPCA were selected to construct the biplots. All these aforementioned processing operations can be done in R software, which is freely available on www.r-project.org (accessed on 28 August 2020), with the robCompositions package.

\section{Results and Discussion}

\subsection{Heavy Metal Concentration of Surface Sediments}

Figure 2 and Table S2 present the concentration bar charts of heavy metals (As, Cd, $\mathrm{Hg}, \mathrm{Cr}, \mathrm{Ni}, \mathrm{Cu}, \mathrm{Pb}$, and $\mathrm{Zn}$ ) in the surface sediment collected from Chagan Lake. The background values refer to the soil eco-geochemical baseline of the alluvial plain of eastern China and the concentrations of heavy metals in the Songnen Plain soil $[45,46]$. The concentrations of heavy metal elements ranged from 2.90 to 14.36 for As, 0.05 to 0.34 for 
Cd, 0.017 to 0.13 for $\mathrm{Hg}$, 24.90 to 72.40 for $\mathrm{Cr}, 13.75$ to 39.70 for $\mathrm{Ni}, 4.80$ to 29.70 for $\mathrm{Cu}, 4.90$ to 69.90 for $\mathrm{Pb}$, and 25.60 to 94.10 for $\mathrm{Zn}$ with all units of $\mathrm{mg} / \mathrm{kg}$, respectively. The average concentrations of the studied heavy metals descended in the order of $\mathrm{Zn}(66.83 \mathrm{mg} / \mathrm{kg})$ $>\mathrm{Cr}(57.60 \mathrm{mg} / \mathrm{kg})>\mathrm{Ni}(29.68 \mathrm{mg} / \mathrm{kg})>\mathrm{Pb}(26.56 \mathrm{mg} / \mathrm{kg})>\mathrm{Cu}(20.73 \mathrm{mg} / \mathrm{kg})>\mathrm{As}$ $(10.01 \mathrm{mg} / \mathrm{kg})>\mathrm{Cd}(0.20 \mathrm{mg} / \mathrm{kg})>\mathrm{Hg}(0.07 \mathrm{mg} / \mathrm{kg})$. The comparison of heavy metals concentrations between the Chagan and other lakes (the Songnen Plain and major lakes in China) showed that the content of heavy metal in the present study was lower than those in the major lakes (Table 2) [47,48], while higher than those in the Nen River, which is the largest tributary of the Songhua River [49]. The variation tendency of heavy metals concentrations was the same as that in the Yueliang Lake flowing into the Nen River, but different from that in the Songhua River [50,51]. The concentration of $\mathrm{Pb}$ in Chagan Lake was much higher than that of the Songhua River and Jingpo Lake, with a lower Cd, Ni, and $\mathrm{Zn}$ concentration compared to the latter two lakes. [51,52]. Here, as a reference river in eco-toxicological studies, the Nen River was the main water source of Chagan Lake from 1984 to 2007.

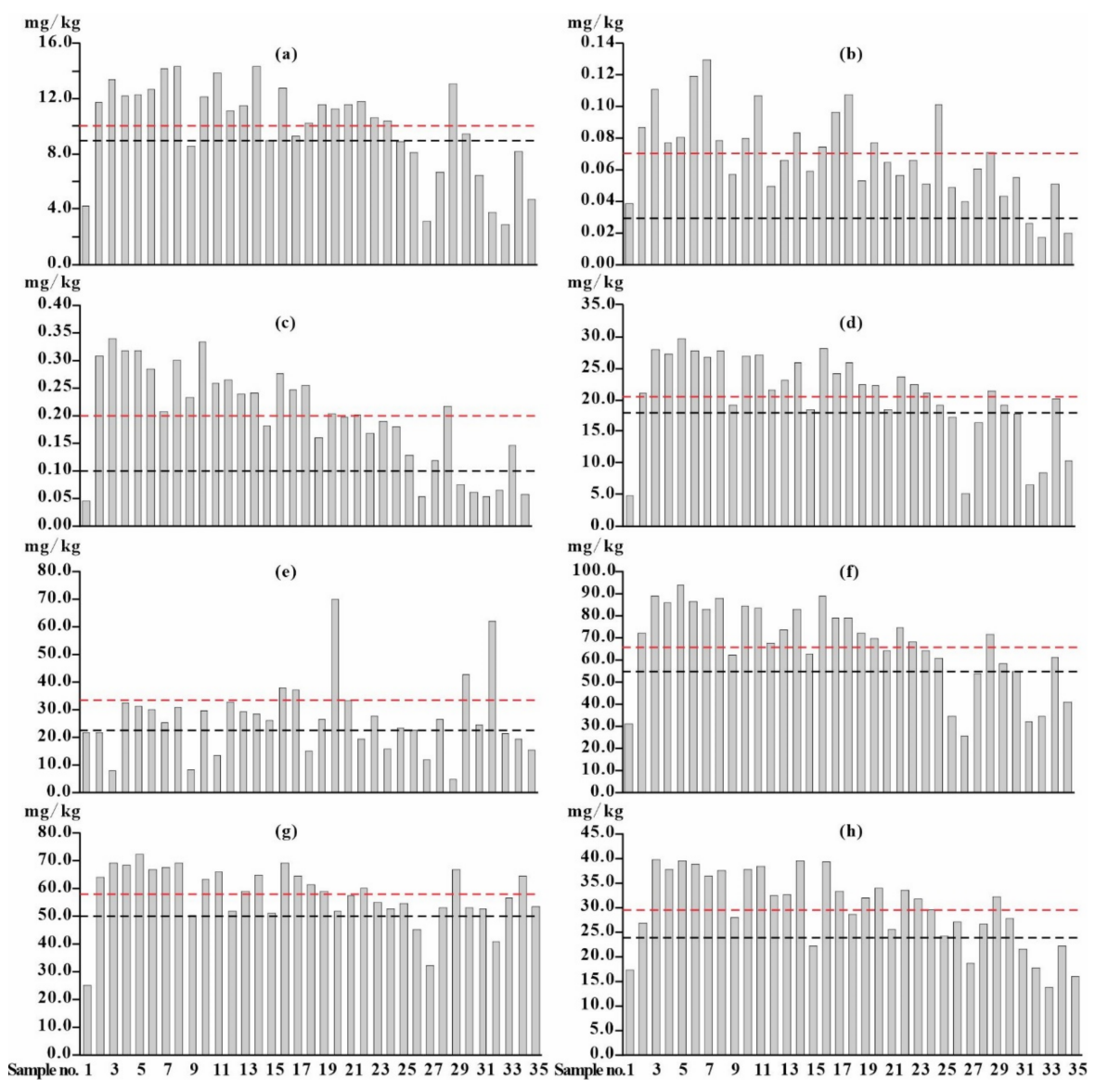

Figure 2. Heavy metals concentrations in the surface sediment from the Chagan Lake. (a) As, (b) $\mathrm{Hg}$, (c) Cd, (d) Cu, (e) Pb, (f) Zn, (g) Cr and (h) Ni. (Black dash line-background value; Red dash line-mean concentration). 
Table 2. Heavy metal concentrations in the surface sediments from Chagan Lake and other selected lakes.

\begin{tabular}{|c|c|c|c|c|c|c|c|c|c|}
\hline \multirow{2}{*}{ Name of the Lake } & \multicolumn{8}{|c|}{ Heavy Metal Concentrations (mg/kg) } & \multirow{2}{*}{ References } \\
\hline & As & $\mathrm{Cd}$ & $\mathrm{Hg}$ & $\mathrm{Cr}$ & $\mathbf{N i}$ & $\mathrm{Cu}$ & $\mathbf{P b}$ & Zn & \\
\hline Chagan Lake & 10.01 & 0.2 & 0.07 & 57.6 & 29.68 & 20.73 & 26.56 & 66.83 & This Study \\
\hline Yueliang Lake & 7.64 & 0.16 & 0.07 & 53.66 & 26.82 & 19.3 & 56.13 & 72.17 & [50] \\
\hline Songhua River & 18.9 & 0.9 & 0.1 & 41.2 & 99 & 44.5 & 13.3 & 107 & [51] \\
\hline Nen River & 5.2 & 0.24 & 0.027 & 26 & 24 & 21 & 5.4 & 54 & [49] \\
\hline Jingpo Lake & 7.28 & 0.48 & 0.113 & 82.8 & 39.3 & 22.4 & 12.1 & 84.6 & [52] \\
\hline $\begin{array}{l}\text { Major Lakes in } \\
\text { Songnen Plain }\end{array}$ & - & - & - & - & 35.07 & 29.09 & 25.57 & 189.78 & [47] \\
\hline Major Lakes in China & 16.39 & 0.497 & 0.076 & 6.29 & 31.81 & 36.89 & 35.37 & 99.52 & {$[48]$} \\
\hline Background Value & 9 & 0.099 & 0.015 & 50 & 24 & 18 & 22 & 54 & {$[45,46]$} \\
\hline
\end{tabular}

\subsection{Chronology and Heavy Metals in Sediment Cores}

\subsubsection{Geological and Chronological Characteristic}

Figure 3a shows the geological features of the sediment core, which can be roughly divided into three parts: the upper part was mainly composed of a grey-black/dark-greyblack clayey sand layer intercalated with high organic matter, which contained plant roots and shells. The middle part was a dark-gray sandy clay layer intercalated with sand spots; the lower part was mainly a dark-grey-black sandy clay layer intercalated with iron rust spots and iron nodules.

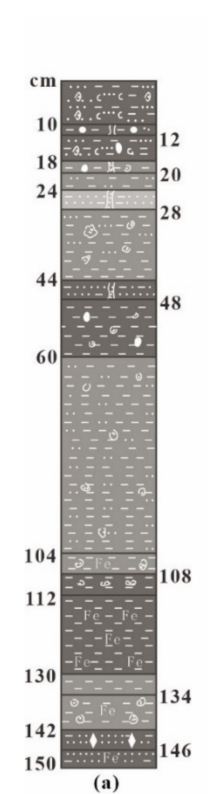

(a)

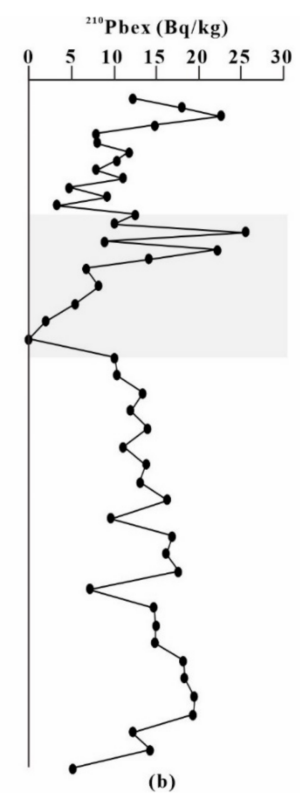

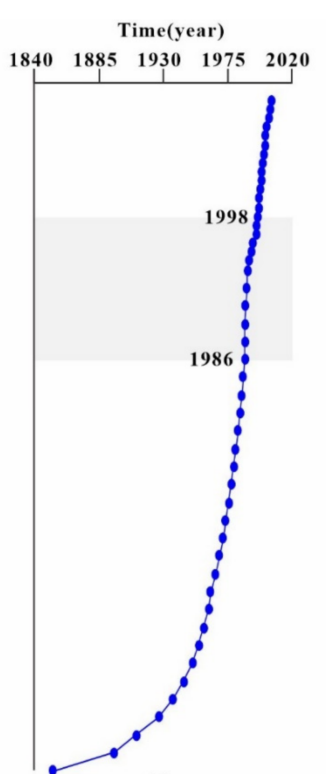

(c)

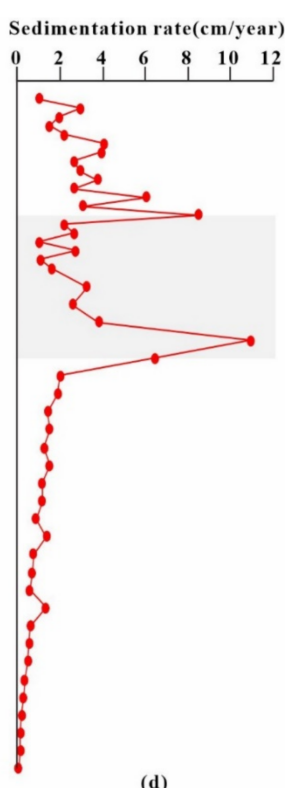

(d)

Figure 3. Geological features (a), specific activity distribution of ${ }^{210} \mathrm{Pbex}(\mathbf{b})$, chronological sequence dated (c), and sedimentation rate by ${ }^{210} \mathrm{~Pb}_{\mathrm{ex}}$ Constant Rate of Supply (CRS) (d) in the sediment core of the Chagan Lake.

In the sediment core, ${ }^{210} \mathrm{~Pb}_{\text {total }}$ ranged from 20.78 to $42.56 \mathrm{~Bq} / \mathrm{kg}$, with an average of $32.82 \mathrm{~Bq} / \mathrm{kg}$; ${ }^{210} \mathrm{~Pb}_{\mathrm{ex}}$ ranged from 0 to $25.46 \mathrm{~Bq} / \mathrm{kg}$, with an average of $12.29 \mathrm{~Bq} / \mathrm{kg}$. The increase in ${ }^{210} \mathrm{~Pb}_{\text {ex }}$ specific activity with a continuously increasing depth was characterized by exponential decay and narrow amplitude oscillation (Figure 3b). The Constant Rate of Supply (CRS) model was applied here to calculate the age of different layers in the sediment core, and the results reflected the sedimentary history over 153 years (Figure 3c). The average deposition rate of the core was calculated as $2.20 \mathrm{~cm} /$ year by the dating results (Figure 3d). The sedimentation rates, lying in $56 \mathrm{~cm}(10.59 \mathrm{~cm} /$ year) and $28 \mathrm{~cm}$ $(8.50 \mathrm{~cm} /$ year) of the sediment core, were obviously higher as peaks corresponding to 
1986 and 1998, respectively. According to the hydrological history of Chagan Lake, the highest water level of Chagan Lake in 1986 reached 131.23 m, which was highly related to the entrance of the Huolinhe and Taoer River flood. Furthermore, the worst flood that happened in Huolinhe and Nenjiang River during 1998, which can be seen as once in hundred years, resulted in the water level of Chagan Lake rising to $132.02 \mathrm{~m}$, which was the highest level in recorded history. These results further prove the accuracy of ${ }^{210} \mathrm{Pbex}$ CRS dating results.

\subsubsection{Concentrations and Distribution of Heavy Metals}

The vertical distributions of eight heavy metals ( $\mathrm{As}, \mathrm{Hg}, \mathrm{Cd}, \mathrm{Cr}, \mathrm{Ni}, \mathrm{Cu}, \mathrm{Pb}$, and $\mathrm{Zn}$ ) in the sedimental core, indicating historical changes of various pollutants associated with contamination sources, are shown in Figure 4. The average concentrations of heavy metals followed the subsequent decreasing order: $\mathrm{Cr}>\mathrm{Zn}>\mathrm{Ni}>\mathrm{Pb}>\mathrm{Cu}>\mathrm{As}>\mathrm{Cd}>\mathrm{Hg}$. Among these elements, each element's mean value, except for $\mathrm{Cd}$, was higher than the background value. The concentration of As increased with depth, and the high concentration was mainly distributed in the lower part of the core $(132-146 \mathrm{~cm})$, while the concentration for $\mathrm{Hg}, \mathrm{Cr}$, and $\mathrm{Pb}$ remained almost unchanged. The $\mathrm{Hg}$ concentration was highest at a depth of $12 \mathrm{~cm}$, suggesting that there may have other potential sources of $\mathrm{Hg}$, probably due to the enrichment of heavy metals incurred by large amounts of coal combustion via the atmosphere subsidence. Moreover, there was a significantly high concentration of $\mathrm{Pb}$ and $\mathrm{Cr}$ at the depth of 128-146 cm, referring to the period 1900-1950, which can be difficult to interpret. The vertical concentration of $\mathrm{Cu}, \mathrm{Cr}, \mathrm{Ni}$, and $\mathrm{Zn}$ basically followed a similar distribution pattern, showing an inverted $\mathrm{C}$-shape, and the high concentration part corresponded to the middle part $(60-104 \mathrm{~cm})$ of the core, which matched the dark gray sandy clay during the period 1970-1986. The continuous increase in heavy metal concentrations could be attributed to the increased volumes of industrial, agricultural, and domestic wastewater during the rapid development period of China's reform and opening-up policy since 1978 [50].

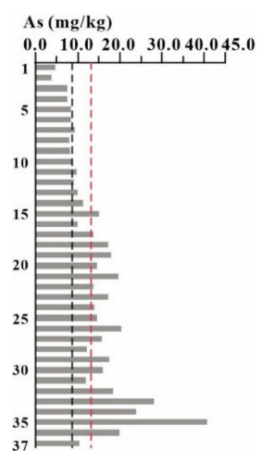

(a)

$\mathrm{Cu}(\mathrm{mg} / \mathbf{k g})$
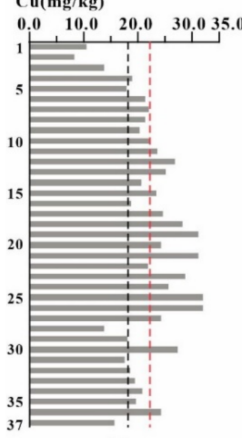

(e)

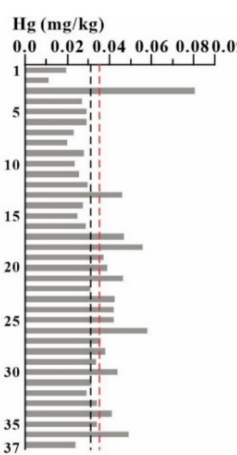

(b)

$\mathrm{Zn}(\mathrm{mg} / \mathrm{kg})$

$\mathrm{Zn}(\mathrm{mg} / \mathrm{kg})$
0.020 .040 .060 .0
80.0100 .0

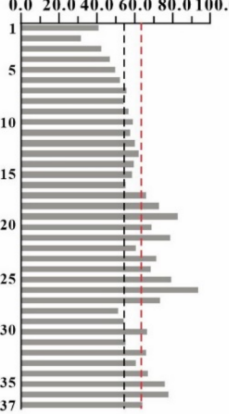

(f)

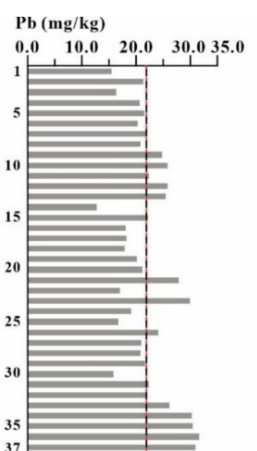

(c)

$\mathrm{Cd}(\mathrm{mg} / \mathrm{kg})$
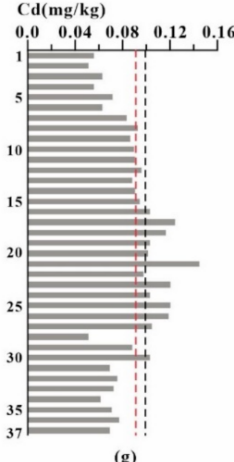

Cr(mg/kg) Geological

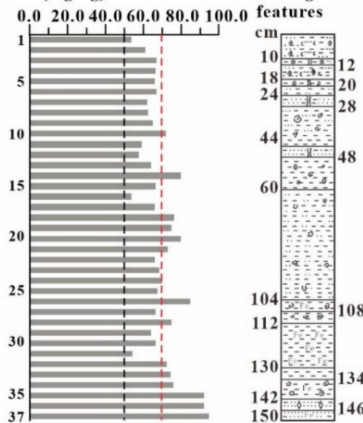

(d)

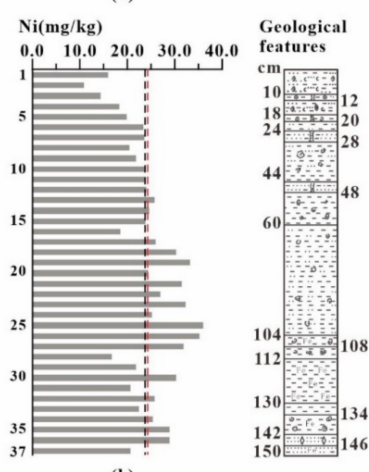

Figure 4. Concentration profiles of heavy metals in the sediment core from the Chagan Lake. (a) As, (b) $\mathrm{Hg}$, (c) $\mathrm{Pb}$, (d) $\mathrm{Cr}$, (e) Cu, (f) $\mathrm{Zn}$, (g) $\mathrm{Cd}$ and (h) Ni. (Black dash line-background value; Red dash line-mean concentration). 


\subsection{Ecological Risk Assessment}

The $E_{i}$ and $R I$ results of heavy metals in the surface sediment and sediment core of Chagan Lake are shown in Table 3. In general, the $E_{i}$ of $\mathrm{As}, \mathrm{Cr}, \mathrm{Cu}, \mathrm{Zn}, \mathrm{Pb}$, and $\mathrm{Ni}$ in both surface samples and sediment core was less than 40 , indicating a low risk to the ecological environment. As for surface samples, the $E_{i}$ of $C d$ ranged from 13.89 to 103.04 (mean 59.81), of which nine samples $(27.51 \%)$ were ranked as low risk, eighteen samples $(51.43 \%)$ were classified as moderate risk, and eight samples (22.86\%) were categorized as relatively high risk. The $E_{i}$ of $\mathrm{Cd}$ in the sediment core ranged from 15.36 to 43.88 (mean 26.76), of which only one sample (3\%) was assessed as moderate risk. In addition, $R I$ in the surface sediment ranged from 57.50 to 283.23 with an average equal to 181.62 , indicating a moderate-low risk. While for $R I$ in the sediment core ranged from 45.82 to 160.17 with an average equal to 107.97 , indicating a low risk.

Table 3. Calculation results of the potential ecological index in the surface sediments and sediment core of Chagan Lake.

\begin{tabular}{cccccccccc}
\hline \multirow{2}{*}{ Items } & \multicolumn{8}{c}{$\boldsymbol{E}_{\boldsymbol{i}}$} & \multirow{2}{*}{$\boldsymbol{R I}$} \\
\cline { 2 - 8 } & $\mathbf{A s}$ & $\mathbf{H g}$ & $\mathbf{C d}$ & $\mathbf{C r}$ & $\mathbf{N i}$ & $\mathbf{C u}$ & $\mathbf{P b}$ & $\mathbf{Z n}$ & \\
\hline Minimum * $^{*}$ & 3.22 & 21.94 & 13.89 & 1.00 & 2.86 & 1.33 & 1.11 & 0.47 & 57.50 \\
Maximum * $^{*}$ & 15.96 & 167.36 & 103.04 & 2.90 & 8.27 & 8.25 & 15.89 & 1.47 & 283.23 \\
Mean * $^{+}$ & 11.13 & 88.56 & 59.81 & 2.30 & 6.18 & 5.76 & 6.04 & 1.24 & 181.02 \\
Minimum $^{+}$ & 4.14 & 13.93 & 15.36 & 2.15 & 2.26 & 2.26 & 2.90 & 0.58 & 45.82 \\
Maximum $^{+}$ & 45.23 & 103.90 & 43.88 & 3.79 & 7.52 & 8.92 & 7.19 & 1.73 & 160.17 \\
Mean $^{*}$ & 15.49 & 45.53 & 26.76 & 2.78 & 5.11 & 6.11 & 5.04 & 1.15 & 107.97 \\
\hline * stands for surface sediments; ${ }^{*}$ stands for sediment core. & & & & &
\end{tabular}

* stands for surface sediments; ${ }^{+}$stands for sediment core.

Box plots of $I_{g e o}$ in the surface sediment and sediment core of Chagan Lake are shown in Figure 5. The mean values of $I_{\text {geo }}$ in the surface sediment were arranged in descending order as follows: $\mathrm{Hg}>\mathrm{Cd}>\mathrm{Ni}>\mathrm{Zn}>\mathrm{Cr}>\mathrm{Pb}>\mathrm{Cu}>\mathrm{As}$. For $\mathrm{Hg}$ and $\mathrm{Cd}$, the $I_{\text {geo }}$ ranged from -1.45 to 1.48 (mean 0.43 ) and from -1.70 to 1.20 (mean 0.20 ), respectively, indicating that the pollution level to be slightly contaminated by heavy metals. The $I_{\text {geo }}$ of $\mathrm{As}, \mathrm{Ni}, \mathrm{Cu}$, and $\mathrm{Zn}$ ranged from -2.75 to 0.22 , showing that the lake heavy was not contaminated on the whole by heavy metals and only slightly contaminated on individual points.

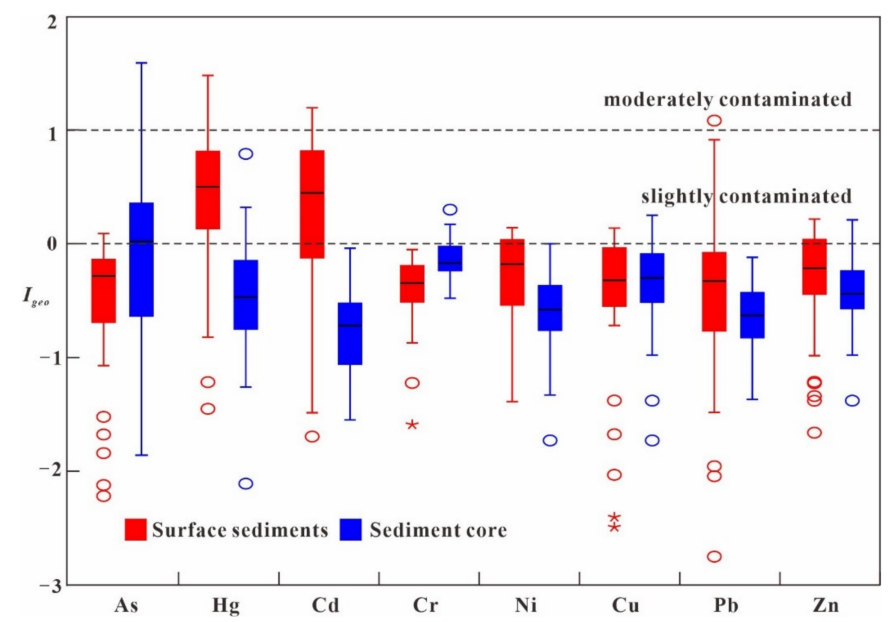

Figure 5. Box plot of $I_{g e o}$ in the surface sediments and sediment core of Chagan Lake.

\subsection{Source Identification}

Figure 6 shows the biplot of PC1 and PC2 obtained from PCA and RPCA for raw data, logarithmic transformation data, and ilr transformed data. Among these datasets, the ilr transformed data, which has been opened and the closure effect eliminated, showed a radial 
pattern as a whole (Figure $6 \mathrm{c}, \mathrm{d}$ ). In contrast, as for the PCA result based on the raw data and logarithmically transformed data, which belong to Aichision space, all elements presented a one-sided trend due to the closure effect (Figure 6a,b). On the other hand, the transformed datasets yielded a higher total variance explained values for PC1, PC2 components than those in raw data. And the PC1 component derived from ilr transformed data with RPCA method accounted for the highest total variance explained values than other datasets, which indicated that the components obtained after eliminating the influence of outliers were more representative. From the element associations perspective, it can be concluded that: (1) the raw data and logarithmically transformed data showed similar element associations (Figure 6a,b), and the corresponding loading values of all elements for PC1 were all positively correlated. Although there existed a slight difference in the PC2 component, the relationship between elements could not be well ascertained. (2) In contrast, the biplot pattern of ilr transformed data was quite different, owing to the opening operation on the dataset, the element association was clearly revealed (Figure $6 c, d$ ). The only difference between element associations was that the RPCA approach eliminates the interference of outliers in the data, enhancing the accuracy of element association selection than the PCA approach. As a result, based on the RPCA with the ilr transformed data, three primary sources can be identified from the association of elements in Figure 6d: (1) Cr, Ni, As, Cu, $\mathrm{Zn}$; (2) $\mathrm{Hg}, \mathrm{Cd}$; (3) $\mathrm{Pb}$.

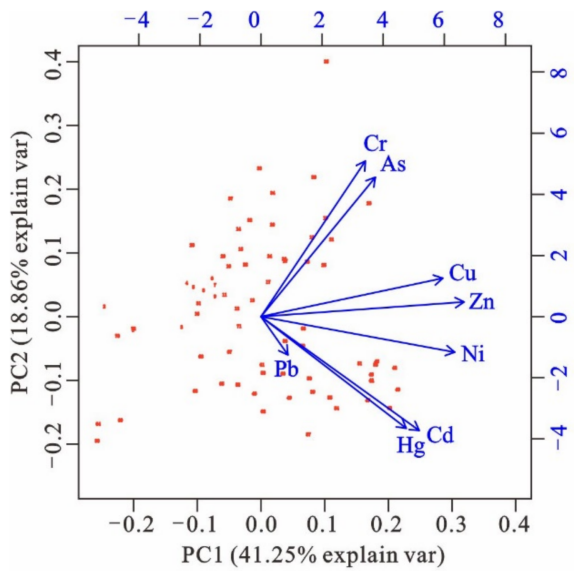

(a)

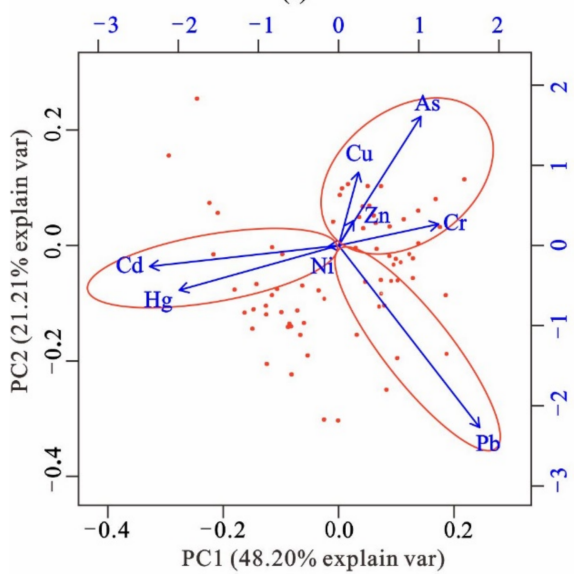

(c)

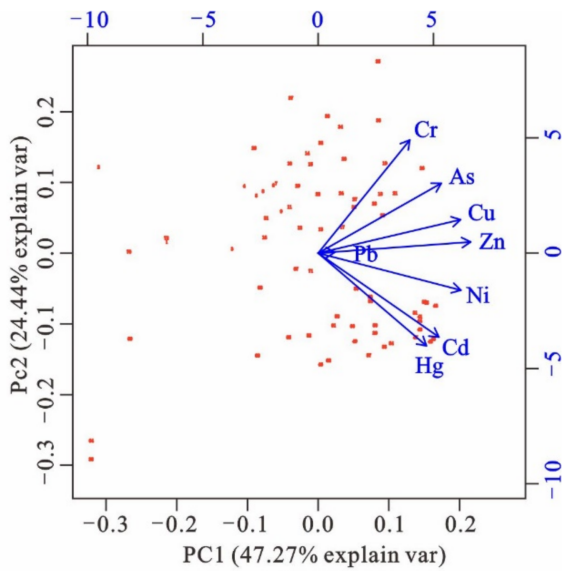

(b)

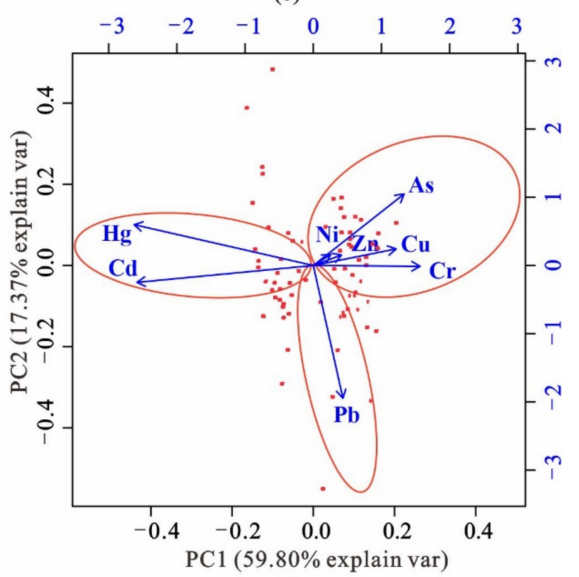

(d)

Figure 6. Principal component analysis/robust principal component analysis (PCA/RPCA) Biplot of different types of datasets in the sediments of Chagan Lake. (a) raw datasets by the PCA, (b) logarithmic transformation datasets by the PCA, (c) ilr transformed datasets by the PCA and (d) ilr transformed datasets by the RPCA.

The first group of elements association included $\mathrm{Cr}, \mathrm{Ni}, \mathrm{Zn}, \mathrm{Cu}$, and As, which can be positively related to the natural source, such as parent rock weathering process and pedo- 
genic process. The formation of sediments experienced rock weathering, transportation, and deposition processes, in which the chemical composition of the sediments is influenced and restricted by the petrochemical composition and epigenetic geochemistry. To figure out the intrinsic relationship between different rock types with contamination sources in the study area, four types of rocks around the study area were collected and studied. As shown in Table 4, the element contents of different rocks varied significantly. Compared with the sediment concentration in Chagan Lake, the average concentration of rocks was higher than that of the sediment. The concentration of Loess-like clayey soil was lower than that of the sediment. These indicate that the elements in lake sediment were differentiated and leached during weathering and leaching processes, resulting in a relative enrichment tendency in the soil/sediment. Figure 7 shows the distribution of $\mathrm{Cr}$ and $\mathrm{Ni}$ with $\mathrm{Al}_{2} \mathrm{O}_{3}$ and $\mathrm{Fe}_{2} \mathrm{O}_{3}$ of sediments. This was highlighted by the positive correlation of $\mathrm{Cr}$ and $\mathrm{Ni}$ with $\mathrm{Al}_{2} \mathrm{O}_{3}$ and $\mathrm{Fe}_{2} \mathrm{O}_{3}$; the latter revealed the enrichment of $\mathrm{Cr}$ and $\mathrm{Ni}$ was related to mafic/ultramafic rocks, which is consistent with the results of previous studies [53,54]. In addition, numerous studies have shown that $\mathrm{Cr}$ and $\mathrm{Ni}$ in the soil/sediment were usually highly correlated. The contents of $\mathrm{Ni}$ and $\mathrm{Cr}$ in soil/sediment were similar to those in the parent material of soil formation and were related to the diagenetic composition and less affected by human activities $[55,56]$. Some researchers supposed that the spatial distribution of $\mathrm{Cr}, \mathrm{Ni}$, and part of $\mathrm{Cu}$ was significantly related to the diagenetic composition [57]. Apart from those mentioned above, the results of the pollution assessment showed that the mean $I_{g e o}$ of heavy metals was less than 0 , which means low or zero potential ecological risk and may indicate few external pollution sources.

Table 4. Comparison table of element contents in sediments and rocks from Chagan Lake and its surrounding areas.

\begin{tabular}{ccccccc}
\hline Name & $\mathbf{C r}$ & $\mathbf{N i}$ & As & $\mathbf{C u}$ & $\mathbf{Z n}$ & References \\
\hline Surface sediment of & 57.60 & 29.68 & 10.01 & 20.73 & 66.83 & This study \\
Chagan Lake & 183.18 & 119.09 & 0.22 & 32.75 & 158.12 & \\
Basalt & 46.90 & 28.34 & 0.79 & 18.41 & 134.98 & \\
Andesite & 2.64 & 3.73 & 0.40 & 6.89 & 54.37 & {$[49]$} \\
Granite & 13.83 & 25.63 & 10.30 & 16.13 & 45.87 & \\
Loess-like clayey soil & 61.64 & 44.20 & 2.93 & 18.55 & 98.33 & \\
Mean content of the rock & & & & & & \\
\hline
\end{tabular}

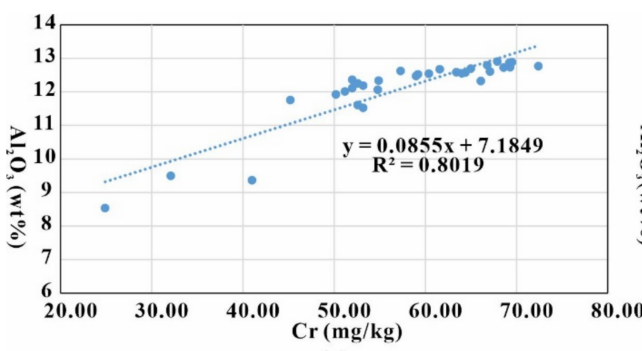

(a)

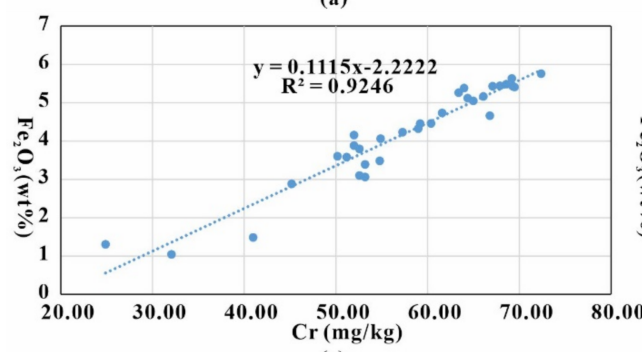

(c)

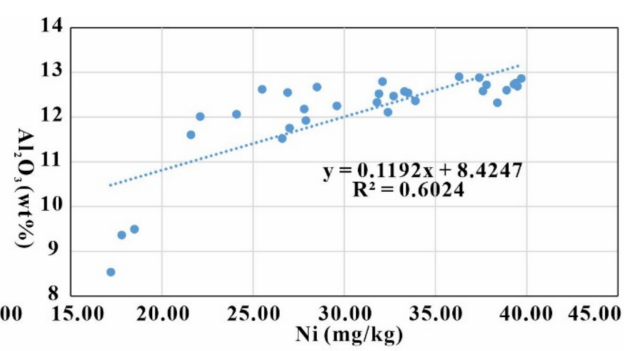

(b)

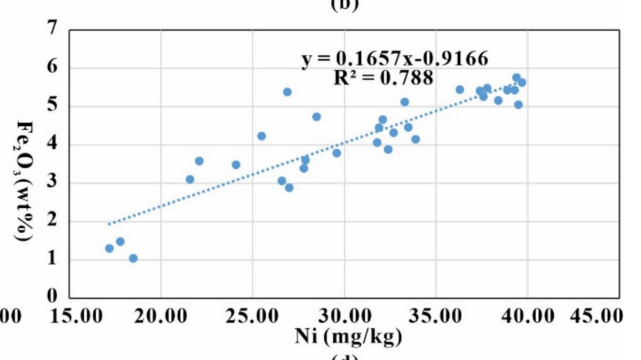

(d)

Figure 7. Distribution diagram of $\mathrm{Cr}$ and $\mathrm{Ni}\left(\mathrm{mg} / \mathrm{kg}\right.$ ) versus $\mathrm{Al}_{2} \mathrm{O}_{3}$ and $\mathrm{Fe}_{2} \mathrm{O}_{3}$ (wt \%) in the sediments of Chagan Lake. (a) Cr versus $\mathrm{Al}_{2} \mathrm{O}_{3}$, (b) Ni versus $\mathrm{Al}_{2} \mathrm{O}_{3}$, (c) Cr versus $\mathrm{Fe}_{2} \mathrm{O}_{3}$, (d) Ni versus $\mathrm{Fe}_{2} \mathrm{O}_{3}$. 
By contrast, the migration ability of As was relatively weak, and the pollution mainly occurred in the middle and lower part of the sediment core, corresponding to a low or zero potential ecological risk to the whole sediment of Chagan Lake. Previous studies also reported that As was mainly affected by coal burning [58]. Furthermore, the thermal power plants in Jilin Province are mostly concentrated in Songyuan City (Huaneng/Changshan thermal power plant). The Changshan thermal power plant, established in 1969, which is closest to Chagan Lake, reached an annual power generation of 3.7 billion kWh. During the initial stage of production, the equipment in Changshan thermal power plant was backward, and the coal combustion was inefficient, resulting in the emission exceeded the standard alert threshold. Furthermore, considering the low temperature in the northeast, scattered peasant households around the lake area used to burn coal for heat against the extreme weather condition, which can also be seen as the main sources of As in the middle and low part of the sediment core.

The second group of element associations included $\mathrm{Hg}$ and $\mathrm{Cd}$, whose concentrations were higher than the background values, which were considered the main contributor to potential ecological risks. The $I_{\text {geo }}$ of $\mathrm{Cd}$ and $\mathrm{Hg}$ indicated that the pollution level of the heavy metals moderately-slightly contaminated the study area. In China, crop production is usually accompanied by the large-scale use of fertilizers and pesticides, which results in heavy metal accumulation in soils and causes significant damage to the environment [59]. The Chagan lake is surrounded by three irrigation districts, including an old irrigation district (Qianguo district) and two new irrigation districts (Da'an and Qian'an districts) covering $5.07 \times 10^{4}, 2.19 \times 10^{4}$, and $1.33 \times 10^{4}$ hectares, respectively [16,17]. Agricultural activities, such as the use of phosphate fertilizer, pesticides, organic manures, and sewage irrigation, generally provide considerable amounts of $\mathrm{Cd}[60,61]$. Previous studies also concluded that longstanding farming practices, such as the application of fertilizers and pesticides, can cause the accumulation of heavy metals, such as $\mathrm{Hg}$ in soils [62,63]. Moreover, the activities of mercury impurities emission, from both the exploitation of oil in the east of Chagan Lake and the surrounding thermal power plants,

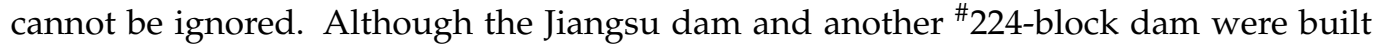
to effectively isolate the oil field operation area from Chagan Lake water (protection area), mercury pollution caused by atmospheric deposition cannot be ruled out. Statistics showed that the mercury emitted to the atmosphere in the form of elemental mercury vapor accounts for $80 \%$ of the considered sources. Considering the above analysis, it can be inferred that agricultural activities and energy development are the main sources of $\mathrm{Cd}$ and $\mathrm{Hg}$.

$\mathrm{Pb}$ was divided into a separate group from the biplot (Figure 6d). Previous studies have shown that traffic transportation (vehicle exhaust, tire wear, and brake wear, etc.) was the key source of heavy metals $\mathrm{Pb}$ pollution in the sediment $[64,65]$. More specifically, $\mathrm{Pb}$ comes from the abrasion of the brakes. As we know, $\mathrm{Pb}$ is a key element in gasoline and diesel, and that vehicle exhaust can enter the soil after atmospheric sedimentation, so vehicle emissions have been regarded as the main source of $\mathrm{Pb}$ in soil/sediment over the past few decades. It has been estimated that automobile exhaust accounts for roughly two-thirds of global Pb emissions [66,67]. Recently, with the development of tourism, the flow of traffic has increased rapidly. On the 2018 National Day, the tourists in the scenic spots of Chagan Lake reached over 310,000, and more than 70,000 vehicles entered the scenic spots, which undoubtedly aggravated the pollution of heavy metals in this area. Additionally, coal mining and combustion emissions could be significant contributors to $\mathrm{Pb}$ in atmospheric deposition [68]. Therefore, $\mathrm{Pb}$ contamination in this area may be attributed to traffic transportation and coal-related industrial activities.

\section{Conclusions}

In this study, we demonstrated the analysis of the pollution level, historical variability, and source identification of heavy metals using surface and core sediments collected from Chagan Lake in Northeastern China. A high-resolution sedimentary record was obtained 
from a sediment core through the ${ }^{210} \mathrm{~Pb}$ chronology technology. The following conclusions are drawn:

(1) The average concentrations of heavy metals in the sediment were generally higher than the background value, indicating that heavy metals are enriched to varying degrees. The surface sediment was not contaminated by most elements except for $\mathrm{Cd}$ and $\mathrm{Hg}$. RI ranged from 57.50 to 283.23 with an average of 181.62 , indicating a moderate-low risk of heavy metals. For the sediment core, there was no contamination on the whole with a low potential ecological risk.

(2) The dating results of ${ }^{210} \mathrm{~Pb}_{\mathrm{ex}}$ CRS accurately reflected the sedimentary history over $153 \mathrm{y}$, and the average sedimentation rate of the core was calculated as $2.20 \mathrm{~cm} /$ year. The sediments in Chagan Lake clearly recorded the temporal evolution of heavy metal pollution within the watershed. The interannual variation of sedimentation rate reflected the change in the natural environment and the influence of anthropogenic activities in Chagan Lake and its watershed.

(3) After an ilr transformation of raw data, the closure effect was eliminated. PCA and RPCA were applied to infer the sources of heavy metal pollution. The results indicated the sediment from Chagan Lake was mainly dominated by three sources: $\mathrm{Cr}, \mathrm{Ni}, \mathrm{As}, \mathrm{Zn}$, and $\mathrm{Cu}$ were mainly derived from natural sources. The main source of $\mathrm{Cd}$ and $\mathrm{Hg}$ were highly related to agricultural activities and energy development. While $\mathrm{Pb}$ originated from vehicular traffic and coal-related industrial activities.

Supplementary Materials: The following are available online at https:/ / www.mdpi.com/2073-444 1/13/7/894/s1, Table S1: Parameter of the detection limits and relative errors, Table S2: The analysis results of heavy metals in the surface sediment from the Chagan Lake.

Author Contributions: Writing-original draft preparation, P.L. and C.Z.; software and data processing, C.Z. and L.H.; writing-review and editing, M.W., Z.W., and X.L.; collecting the samples, Y.L. and S.C.; funding acquisition, L.H., P.L., and M.W. All authors have read and agreed to the published version of the manuscript.

Funding: This work was supported by the National Natural Science Foundation of Guangxi (Grant No. 2018GXNSFAA281022) and the National Key R\&D Program of China (2016YFC0600603); the Doctoral Research Foundation of Guilin University of Technology (Grant No. GUTQDJJ2019166).

Institutional Review Board Statement: Not applicable.

Informed Consent Statement: Not applicable.

Data Availability Statement: The data presented in this study are available on request from the corresponding author.

Acknowledgments: Authors want to express their gratitude to the Institute of Environment and Sustainable Development in Agriculture, Chinese Academy of Agricultural Sciences (CAAS).

Conflicts of Interest: The authors declare no conflict of interest.

\section{References}

1. Zhang, Y.; Han, Y.; Yang, J.; Zhu, L.; Zhong, W. Toxicities and risk assessment of heavy metals in sediments of Taihu Lake, China, based on sediment quality guidelines. J. Environ. Sci. 2017, 62, 31-38. [CrossRef]

2. Talbot, M.R.; Lærdal, T. The Late pleistocene-holocene palaeolimnology of Lake Victoria, East Africa, based upon elemental and isotopic analyses of sedimentary organic matter. J. Paleolimnol. 2000, 23, 141-164. [CrossRef]

3. Wang, J.J;; Bao, J.G.; Li, L.Q. Sources of heavy metal pollutions in sediments of Lake Donghu and their relationship with an-thropogenic activities. Environ. Sci. Technol. 2010, 33, 84-90.

4. Ji, B.; Hang, X.S.; Liang, B.; Tang, X.Y.; Wang, W.L. Advances in heavy metals contamination of lake sediment. Pollut. Control. Technol. 2013, 26, 33-40.

5. Satapathy, S.; Panda, C.R. Source identification, environmental risk assessment and human health risks associated with toxic elements present in a coastal industrial environment, India. Environ. Geochem. Health 2018, 40, 2243-2257. [CrossRef] [PubMed]

6. Patel, P.; Raju, N.J;; Reddy, B.C.S.R.; Suresh, U.; Sankar, D.B.; Reddy, T.V.K. Heavy metal contamination in river water and sediments of the Swarnamukhi River Basin, India: Risk assessment and environmental implications. Environ. Geochem. Health 2018, 40, 609-623. [CrossRef] [PubMed] 
7. Li, R.R.; Zhang, G.X.; Wei, X.H.; Liu, Y.; Zhang, L.; Sun, S. The evolutional characteristics of water environment of Chagan Lake Wetland. Sci. Geogr. Sin. 2014, 34, 762-768. [CrossRef]

8. Rothwell, J.J.; Evans, M.G.; Allott, T.E.H. Sediment-Water Interactions in an eroded and heavy metal contaminated peatland catchment, Southern Pennines, UK. Water Air Soil Pollut. Focus 2006, 6, 669-676. [CrossRef]

9. Ting, D.S.; Appan, A. General characteristics and fractions of phosphorus in aquatic sediments of two tropical reservoirs. Water Sci. Technol. 1996, 34, 53-59.

10. Ramamoorthy, S.; Rust, B.R. Heavy metal exchange processes in sediment-water systems. Environ. Earth Sci. 1978, 2, 165-172. [CrossRef]

11. Li, Z.Q.; Fang, P.; Huang, B.; Lu, S.Y.; Wan, Q.; Xiong, J.; Zhang, G.G. Distribution and ecological risk assessment of nitrogen phosphorus and heavy metals in surface sediments of typical internal lakes in Dongting Lake area. Res. Environ. Sci. 2020, 33, 1409-1420.

12. Liu, Z.Y. Problems and suggestions of ecological environment in Jilin province. Rural Econ. Sci. Technol. 2020, 31, 53-54.

13. Ran, Y.; Li, L. The brief analysis of ecological environment problems and ecological province construction in Jilin Province. Environ. Manag. China 2008, 6, 1-2.

14. Bu, X.J.; Chai, S.L.; Zhang, Q.W.; Xu, X.C. The spatial distributions of elements in sediments of lake Chagan in west Jilin Province. J. Arid Land Resour. Environ. 2009, 23, 179-184.

15. Yang, Z.; Zang, S.Y.; Qu, G.; Sun, L. Comparative analysis of grain size characteristics and environmental significance of sediments from Bosten Lake and Chagan Lake. Environ. Sci. Technol. 2020, 43, 198-208.

16. Liu, X.M.; Zhang, G.X.; Sun, G.Z.; Wu, Y.; Chen, Y.Q. Assessment of lake water quality and eutrophication risk in an ag-ricultural irrigation area: A Case Study of the Chagan Lake in Northeast China. Water Sui 2019, 11, 2380.

17. Liu, X.; Zhang, G.; Zhang, J.; Xu, Y.J.; Wu, Y.; Wu, Y.; Sun, G.; Chen, Y.; Ma, H. Effects of irrigation discharge on salinity of a large freshwater lake: A case study in Chagan Lake, Northeast China. Water 2020, 12, 2112. [CrossRef]

18. Wang, F.; Ding, Q.; Zhang, L.; Wang, M.; Wang, Q. Analysis of land surface deformation in Chagan Lake Region Using TCPInSAR. Sustain. J. Rec. 2019, 11, 5090. [CrossRef]

19. Guo, W.; Wang, Y.; Shi, J.; Zhao, X.; Xie, Y. Sediment information on natural and anthropogenic-induced change of connected water systems in Chagan Lake, North China. Environ. Geochem. Health 2019, 42, 795-808. [CrossRef] [PubMed]

20. Wang, Y.; Liu, D.; Song, K.; Du, J.; Wang, Z.; Zhang, B.; Tang, X.; Lei, X.; Wu, Y. Characterization of water constituents spectra absorption in Chagan Lake of Jilin Province, Northeast China. Chin. Geogr. Sci. 2011, 21, 334-345. [CrossRef]

21. Ye, Z.; Chen, J.; Gao, L.; Liang, Z.; Li, S.; Li, R.; Jin, G.; Shimizu, Y.; Onodera, S.-I.; Saito, M.; et al. 210Pb dating to investigate the historical variations and identification of different sources of heavy metal pollution in sediments of the Pearl River Estuary, Southern China. Mar. Pollut. Bull. 2020, 150, 110670. [CrossRef]

22. San Miguel, E.G.; Bolı, X.; Var, J.P.; Garc1, X.; Tenorio, R.A. Vertical distribution of Thisotope ratios, 210Pb, 226Ra and 137Cs in sediment cores from an estuary affected by anthropogenic releases. Sci. Total Environ. 2004, 318, 143-157. [CrossRef]

23. Wu, Z.; He, M.; Lin, C.; Fan, Y. Distribution and speciation of four heavy metals (Cd, Cr, Mn and Ni) in the surficial sediments from estuary in daliao river and yingkou bay. Environ. Earth Sci. 2010, 63, 163-175. [CrossRef]

24. Xiao, Q.; Zong, Y.T.; Lu, S.G. Assessment of heavy metal pollution and human health risk in urban soils of steel industrial city (Anshan), Liaoning, Northeast China. Ecotoxicol. Environ. Saf. 2015, 120, 377-385.

25. Wang, X.; Liu, B.; Zhang, W. Distribution and risk analysis of heavy metals in sediments from the Yangtze River Estuary, China. Environ. Sci. Pollut. Res. 2020, 27, 10802-10810. [CrossRef]

26. Shen, F.; Mao, L.; Sun, R.; Du, J.; Tan, Z.; Ding, M. Contamination Evaluation and Source Identification of Heavy Metals in the Sediments from the Lishui River Watershed, Southern China. Int. J. Environ. Res. Public Health 2019, 16, 336. [CrossRef]

27. Hakanson, L. An ecological risk index for aquatic pollution control.a sedimentological approach. Water Res. 1980, 14, 975-1001. [CrossRef]

28. Xu, Z.Q.; Ni, S.J.; Tuo, X.G.; Zhang, C.J. Calculation of heavy metals' toxicity coefficient in the evaluation of potential ecological risk index. Environ. Sci. Tech. 2008, 31, 112-115.

29. Teng, Y.G.; Tuo, X.G.; Ni, S.J.; Zhang, C.J. Applying geoaccumulation index to assess heavy metal pollution in sediment: In-fluence of different geochemical background. Environ. Sci. Technol. 2002, 25, 7-9.

30. Hui, Y.; Yuan, S.Y.; Li, M.Y.; Xiao, J. Evaluation of heavy metal contamination in agricultural topsoils in suburban Xuchang City, China. Environ. Earth Sci. 2015, 74, 2475-2480.

31. Hussain, R.; Khattak, S.A.; Shah, M.T.; Ali, L. Multistatistical approaches for environmental geochemical assessment of pol-lutants in soils of Gadoon Amazai Industrial Estate, Pakistan. J. Soil. Sediment. 2015, 15, 1119-1129. [CrossRef]

32. Zheng, X.; Zhao, W.; Yan, X.; Shu, T.; Xiong, Q.; Chen, F. Pollution characteristics and health risk assessment of airborne heavy metals collected from beijing bus stations. Int. J. Environ. Res. Public Health 2015, 12, 9658-9671. [CrossRef]

33. Müller, G.; Putz, G. Index of geoaccumulation in sediments of the Rhine River. Geojournal 1969, 2, 108-118.

34. Pawlowsky-Glahn, V.; Egozcue, J.J. Compositional data and their analysis: An introduction. Geol. Soc. Lond. Spéc. Publ. 2006, 264, 1-10. [CrossRef]

35. Campbell, G.P.; Curran, J.M.; Miskelly, G.M.; Coulson, S.; Yaxley, G.M.; Grunsky, E.C.; Cox, S.C. Compositional data analysis for elemental data in forensic science. Forensic Sci. Int. 2009, 188, 81-90. [CrossRef] [PubMed] 
36. Reimann, C.; Filzmoser, P.; Fabian, K.; Hron, K.; Birke, M.; Demetriades, A.; Dinelli, E.; Ladenberger, A. The concept of compositional data analysis in practice-Total major element concentrations in agricultural and grazing land soils of Europe. Sci. Total. Environ. 2012, 426, 196-210. [CrossRef]

37. Filzmoser, P.; Hron, K.; Reimann, C. Univariate statistical analysis of environmental (compositional) data: Problems and pos-sibilities. Sci. Total. Environ. 2009, 407, 6100-6108. [CrossRef] [PubMed]

38. Aitchison, J. The statistical analysis of compositional data. J. R. Stat. Soc. B 1982, 44, 139-177. [CrossRef]

39. Filzmoser, P.; Hron, K.; Templ, M. Applied Compositional Data Analysis; Springer Science and Business Media LLC: Berlin/Heidelberg, Germany, 2018; p. 288.

40. Zuo, R.; Carranza, E.J.M.; Wang, J. Spatial analysis and visualization of exploration geochemical data. Earth Sci. Rev. 2016, 158, 9-18. [CrossRef]

41. Huber, P.J. Robust Statistics. In International Encyclopedia of Statistical Science; Lovric, M., Ed.; Springer: Berlin/Heidelberg, Germany, 2011; pp. 1248-1251.

42. Wang, B.H. Robust principal component analysis method and its application. Stat. Res. 2007, 24, 72-76.

43. Pison, G.; Rousseeuw, P.J.; Filzmoser, P.; Croux, C. Robust factor analysis. J. Multivar. Anal. 2003, 84, 145-172. [CrossRef]

44. Hubert, M.; Rousseeuw, P.J.; Verboven, S. A fast method for robust principal components with applications to chemometrics. Chemom. Intell. Lab. Syst. 2002, 60, 101-111. [CrossRef]

45. Zhu, L.X.; Ma, S.M.; Wang, Z.F. Soil Eco-geochemical baseline in alluvial plains of eastern China. Geol. China 2006, 33, 1400-1405.

46. Liu, X.J.; Zhao, Y.L. A preliminary study on the background values of eight heavy metallic elements and relevant factors on the Songnen Plain. J. Northeast. Agric. Univ. 1987, 18, 113-118.

47. Yu, W.H.; Wang, J.J.; Zang, S.Y. The spatial variability characteristics and potential ecological risk assessment of heavy metals of lake sediments in the Songnen Plain. Sci. Geogr. Sin. 2012, 32, 1000-1005.

48. Ding, Z.Y.; Pu, J.; Jilili, A. Heavy metal contamination characteristics and its assessment in surface sediments of major Lakes in China. Environ. Eng. 2017, 35, 136-142.

49. Song, G.L.; Liu, Z. Study on the background value of some elemants in deposit sediment of the Nenjiang drainage. Nat. Sci. J. Harbin Normal Univ. 1988, 4, 100-105.

50. Gao, L.N. Environmental Geochemistry of Heavy Metals in Yueliang Lake in West Jilin Province. Master's Thesis, Jilin University, Changchun, China, 2013.

51. Liu, B.L.; Diao, G.L.; Han, X.; Zhao, B.; Xue, M.Y.; Cui, X.T.; Niu, X. Spatial distribution and ecological risk assessment of heavy metals in surface sediments from Songhua River. Sci. Technol. Eng. 2015, 15, 140-145.

52. Wang, X.J.; Liu, Y.Q.; She, Z.S. Heavy metals in the sediments of Jingpo Lake. Chinese J. Environ. Eng. 1990, 11, 46-51.

53. Bianchini, G.; Natali, C.; Di Giuseppe, D.; Beccaluva, L. Heavy metals in soils and sedimentary deposits of the Padanian Plain (Ferrara, Northern Italy): Characterisation and biomonitoring. J. Soils Sediments 2012, 12, 1145-1153. [CrossRef]

54. Bianchini, G.; Di Giuseppe, D.; Natali, C.; Beccaluva, L. Ophiolite inheritance in the Po plain sediments: Insights on heavy metals distribution and risk assessment. Ofioliti 2013, 38, 1-14.

55. Lv, J.; Liu, Y.; Zhang, Z.; Dai, J.; Dai, B.; Zhu, Y. Identifying the origins and spatial distributions of heavy metals in soils of Ju country (Eastern China) using multivariate and geostatistical approach. J. Soils Sediments 2015, 15, 163-178. [CrossRef]

56. Zhou, F.; Liu, Y.; Guo, H. Application of Multivariate statistical methods to water quality assessment of the watercourses in northwestern new territories, Hong Kong. Environ. Monit. Assess. 2006, 132, 1-13. [CrossRef] [PubMed]

57. Shah, M.; Araa, J.; Muhammada, S.; Khan, S. Health Risk assessment via surface water and sub-surface water consumption in the mafic and ultramafic terrain, Mohmand Agency, Northern Pakistan. J. Geochem. Explor. 2012, 118, 60-67. [CrossRef]

58. Tan, J.; Zhang, L.; Zhou, X.; Duan, J.; Li, Y.; Hu, J.; He, K. Chemical characteristics and source apportionment of PM 2.5 in Lanzhou, China. Sci. Total. Environ. 2017, 601, 1743-1752. [CrossRef] [PubMed]

59. Sun, L.; Guo, D.; Liu, K.; Meng, H.; Zheng, Y.; Yuan, F.; Zhu, G. Levels, sources, and spatial distribution of heavy metals in soils from a typical coal industrial city of Tangshan, China. Catena 2019, 175, 101-109. [CrossRef]

60. Shao, D.; Zhan, Y.; Zhou, W.; Zhu, L. Current status and temporal trend of heavy metals in farmland soil of the Yangtze River Delta Region: Field survey and meta-analysis. Environ. Pollut. 2016, 219, 329-336. [CrossRef]

61. Zhao, Y.; Yan, Z.; Qin, J.; Xiao, Z. Effects of long-term cattle manure application on soil properties and soil heavy metals in corn seed production in Northwest China. Environ. Sci. Pollut. Res. 2014, 21, 7586-7595. [CrossRef]

62. Mamut, A.; Eziz, M.; Mohammad, A.; Anayit, M. The spatial distribution, contamination, and ecological risk assessment of heavy metals of farmland soils in Karashahar-Baghrash oasis, northwest China. Hum. Ecol. Risk Assess. Int. J. 2017, 23, 1300-1314. [CrossRef]

63. Baltas, H.; Sirin, M.; Gökbayrak, E.; Ozcelik, A.E. A case study on pollution and a human health risk assessment of heavy metals in agricultural soils around Sinop province, Turkey. Chemosphere 2020, 241, 125015. [CrossRef]

64. Wang, G.; Zeng, C.; Zhang, F.; Zhang, Y.; Scott, C.A.; Yan, X. Traffic-related trace elements in soils along six highway segments on the Tibetan Plateau: Influence factors and spatial variation. Sci. Total. Environ. 2017, 581, 811-821. [CrossRef] 
65. Zhang, H.; Wang, Z.; Zhang, Y.; Ding, M.; Yili, Z. Identification of traffic-related metals and the effects of different environments on their enrichment in roadside soils along the Qinghai-Tibet highway. Sci. Total. Environ. 2015, 521, 160-172. [CrossRef] [PubMed]

66. Guo, W.; Zhang, H.; Cui, S.; Xu, Q.; Tang, Z.; Gao, F. Assessment of the distribution and risks of organochlorine pesticides in core sediments from areas of different human activity on Lake Baiyangdian, China. Stoch. Environ. Res. Risk Assess. 2014, 28, 1035-1044. [CrossRef]

67. Cui, Z.; Wang, Y.; Zhao, N.; Yu, R.; Xu, G.; Yu, Y. Spatial Distribution and Risk Assessment of Heavy Metals in Paddy Soils of Yongshuyu Irrigation Area from Songhua River Basin, Northeast China. Chin. Geogr. Sci. 2018, 28, 797-809. [CrossRef]

68. Liang, J.; Feng, C.; Zeng, G.; Gao, X.; Zhong, M.; Li, X.; Li, X.; He, X.; Fang, Y. Spatial distribution and source identification of heavy metals in surface soils in a typical coal mine city, Lianyuan, China. Environ. Pollut. 2017, 225, 681-690. [CrossRef] [PubMed] 